Website : http://yustisia.unmermadiun.ac.id/index.php/yustisia

\title{
Perlindungan Pemilik Rahasia Dagang Dalam Perjanjian Waralaba
}

\author{
Anik Tri Haryani \\ Dosen Ilmu Hukum, Universitas Merdeka Madiun, JL.Serayu No.79, Madiun, 63133 \\ E-mail: anik@unmer-madiun.ac.id
}

\begin{abstract}
Tight business competition requires creativity for entrepreneurs to stay competitive by seeking new breakthroughs in developing their businesses. Many franchise models are chosen to develop businesses. One of the criteria for franchising is the Intellectual Property Rights that have been registered including trade secrets. The purpose of this study is to examine the legal protection of trade secret owners in a franchise agreement, and legal consequences if there is a violation of trade secrets in the franchise agreement. The method used in this study is juridical normative with a law approach and conceptual approach. The results of the research show that the protection of trade secrets in the franchise agreement can be done by making an agreement which contains a confidential information, non disclosure agreement clause, a non compete agreement as well as a non solicitation agreement clause. Legal consequences in the event of a violation of trade secrets in the franchise agreement can be prosecuted civilly by paying compensation through a lawsuit to court or can be resolved through arbitration or alternative dispute resolution. In addition, it can also be prosecuted according to Article 17 paragraph (1) of Law Number 30 of 2000 concerning Trade Secrets with the penalty of imprisonment of a maximum of two years and a maximum fine of three hundred million rupiah.
\end{abstract}

Keywords : Protection; Trade Secrets; Franchising.

\begin{abstract}
Abstrak
Persaingan bisnis yang semakin ketat membutuhkan kreatifitas bagi para pengusaha untuk tetap bisa bersaing dengan mencari terobosan baru dalam mengembangkan usahanya. Model waralaba banyak dipilih untuk mengembangkan usaha. Salah satu kriteria waralaba adalah Hak Kekayaan Intelektual yang telah terdaftar termasuk rahasia dagang. Tujuan penelitian ini untuk mengkaji perlindungan hukum terhadap pemilik rahasia dagang dalam perjanjian waralaba, dan akibat hukum jika terjadi pelanggaran terhadap rahasia dagang dalam perjanjian waralaba. Metode yang digunakan dalam penelitian ini adalah yuridis normative dengan pendekatan undang-undang dan pendekatan konseptual. Hasil penelitian menunjukkan perlindungan terhadap rahasia dagang dalam perjanjian waralaba dapat dilakukan dengan membuat perjanjian yang memuat klausul confidential agreement, non disclosure agreement, non compete agreement juga klausul non solicitation agreement. Akibat hukum jika terjadi pelanggaran terhadap rahasia dagang dalam perjanjian waralaba adalah dapat dituntut secara perdata dengan membayar ganti rugi melalui gugatan ke pengadilan atau dapat diselesaikan melalui jalur arbitrase atau alternatif penyelesaian sengketa. Selain itu dapat juga dituntut secara pidana sesuai pasal 17 ayat (1) UndangUndang Nomor 30 tahun 2000 tentang Rahasia Dagang dengan ancaman hukuman pidana penjara paling lama dua tahun dan denda paling banyak tiga ratus juta rupiah.
\end{abstract}

Kata Kunci : Perlindungan; Rahasia Dagang; Waralaba. 
Website : http://yustisia.unmermadiun.ac.id/index.php/yustisia

\section{A. PENDAHULUAN}

Perkembangan Ilmu Pengetahuan dan Teknologi yang semakin pesat berpengaruh terhadap perkembangan ekonomi masyarakat. Laju pertumbuhan bisnis pun semakin pesat dengan adanya berbagai macam perjanjian bisnis. Banyak model perjanjian bisnis yang beredar di masyarakat seperti perjanjian bisnis kuliner, fashion, bisnis online, waralaba dan sebagainya. Persaingan bisnis pun semakin ketat sehingga membutuhkan kreatifitas bagi para pengusaha untuk tetap bisa bersaing dengan mencari terobosan baru dalam mengembangkan usahanya. Hal yang paling banyak kita lihat di masyarakat adalah semakin maraknya bisnis kuliner yang dikembangkan untuk memperluas usaha dengan model perjanjian waralaba.

Waralaba merupakan salah satu bentuk format bisnis dimana pihak pertama disebut pemberi waralaba dan pihak kedua yang disebut penerima waralaba untuk mendistribusikan barang/jasa dalam lingkup area geografis dan periode wakru tertentu dengan mempergunakan merek, logo, dan sistem operasi yang dimiliki dan dikembangkan oleh pemberi waralaba. Pemberian hak ini dalam bentuk perjanjian waralaba antara subyek hukum yang satu dengan subyek hukum yang lain untuk

Suatu industri yang mendistribusikan barang/jasa dalam lingkup area geografis dan periode waktu tertentu dengan mempergunakan merek, logo, dan sistem operasi yang dimiliki dan dikembangkan oleh pemberi waralaba dimana subyek hukum yang satu berhak atas prestasi dan begitu juga subyek hukum yang lain berkewajiban untuk melaksanakan prestasinya sesuai dengan yang telah disepakati. ${ }^{1}$

Pasal 1 Peraturan Pemerintah Republik Nomor 42 Tahun 2007 tentang Waralaba menyebutkan bahwa waralaba adalah hak khusus yang dimiliki oleh orang perseorangan atau badan usaha terhadap sistem bisnis dengan ciri khas usaha dalam rangka memasarkan barang dan/atau jasa yang telah terbukti berhasil dan dapat dimanfaatkan dan/atau digunakan oleh pihak lain berdasarkan perjanjian waralaba. ${ }^{2}$

Pasal 3 menegaskan bahwa salah satu kriteria waralaba adalah Hak Kekayaan Intelektual yang telah terdaftar, yang dimaksud dengan Hak Kekayaan Intelektual yang telah terdaftar tersebut adalah Hak Kekayaan Intelektual yang terkait dengan usaha seperti merek, hak cipta, paten, dan rahasia dagang, sudah didaftarkan dan mempunyai sertifikat atau sedang dalam proses pendaftaran di instansi yang berwenang. ${ }^{3}$

Bisnis waralaba berbeda dengan bisnis lainnya karena bisnis ini tidak hanya sekedar menjual produk tetapi lebih luas lagi berkaitan dengan HKI ( Hak Kekayaan Intelektual ). ${ }^{4}$ Rahasia dagang merupakan salah satu kekayaan intelektual yang terkait dengan bisnis waralaba. Rahasia dagang merupakan aset perusahaan yang sangat berharga yang harus dijaga kerahasiaaannya, tidak semua pihak dapat mengetahui dan mengakses rahasia dagang perusahaan. Untuk menjaga agar rahasia dagang tetap terlindungi dalam perjanjian waralaba tentunya para pihak harus mempunyai itikad baik dalam menjalankan perjanjian bisnis waralaba tersebut, terutama penerima waralaba dan karyawan yang bekerja untuk perusahaan.

\footnotetext{
${ }^{1}$ Bella Katrinasari, Hernawan Hadi, 2017, Tinjauan Hukum Terhadap Wanprestasi Royalty Rahasia Dagang Dalam Perjanjian Waralaba, Privat Law, Vol. V, Januari 2017, Universitas Sebelas Maret, Surakarta, hal. 86

2 Anik Tri Haryani, 2017, Perlindungan Hukum HAKI Dalam Perjanjian Waralaba, Justitia Merdeka, Volume 3, Nomor 1, Maret 2017, LPPM, Universitas Merdeka Madiun, hlm. 86

3 ibid

${ }^{4}$ Bella Katrinasari, Hernawan Hadi, op cit, hlm. 87
}

Volume 4 Nomor 2 September 2018, YUSTISIA MERDEKA | 139 
Website : http://yustisia.unmermadiun.ac.id/index.php/yustisia

\section{B. RUMUSAN MASALAH}

Berdasarkan latar belakang tersebut diatas maka rumusan masalah dalam penelitian ini adalah :

1. Bagamanakah perlindungan hukum terhadap pemilik rahasia dagang dalam perjanjian waralaba?

2. Apakah akibat hukum jika terjadi pelanggaran terhadap rahasia dagang dalam perjanjian waralaba?

\section{METODE PENELITIAN}

Dalam penelitian ini, pendekatan yang digunakan adalah pendekatan undang-undang (statute approach) dan pendekatan konseptual (conceptual approach).

Pendekatan undang-undang (statute approach) dilakukan dengan menelaah semua undang-undang dan regulasi yang bersangkut paut dengan isu hukum yang sedang ditangani. ${ }^{5}$ Fakta yang ada dikaitkan dengan peraturan perundang-undangan yang mengaturnya dan yang masih berlaku. Undang-undang dan regulasi yang digunakan dalam penelitian ini adalah Undang-Undang dan semua peraturan yang berhubungan dengan waralaba yaitu Peraturan Pemerintah Nomor 42 Tahun 2007 tentang Waralaba, dan Peraturan Menteri Perdagangan Republik Indonesia Nomor 31/M-DAG/PER/8/2008 tentang Penyelenggaraan Waralaba, Undang-Undang Nomor 30 tahun 2000 tentang Rahasia Dagang.

Kemudian setelah metode pendekatan undang-undang (statute approach) digunakan, selanjutnya yang digunakan adalah pendekatan konseptual (conceptual approach). Pendekatan konseptual (conceptual approach) beranjak dari pandangan-pandangan dan doktrin-doktrin yang berkembang di dalam ilmu hukum. ${ }^{6}$ Dalam penulisan ini, pendekatan konseptual (conceptual approach) digunakan adalah pandangan-pandangan dan doktrindoktrin di dalam perjanjian waralaba.

\section{Bahan Hukum}

Untuk memecahkan suatu rumusan masalah, diperlukan adanya sumber-sumber penelitian. Sumber-sumber tersebut dapat dibedakan menjadi 2 (dua), yaitu bahan-bahan hukum primer dan bahan-bahan hukum sekunder. Bahan hukum primer merupakan bahan hukum yang bersifat autoritatif, artinya mempunyai kekuasaan. ${ }^{7}$ Bahan-bahan hukum primer terdiri dari perundang-undangan, catatan-catatan resmi atau risalah dalam pembuatan perundang-undangan, dan putusan-putusan hakim. ${ }^{8}$ Sumber bahan hukum primer dalam penelitian ini, antara lain Peraturan Pemerintah Republik Nomor 42 Tahun 2007 tentang Waralaba dan Peraturan Menteri Perdagangan Republik Indonesia Nomor 31/MDAG/PER/8/2008 tentang Penyelenggaraan Waralaba, Undang-Undang Nomor 30 Tahun 2000 tentang Rahasia Dagang.

Selain menggunakan bahan-bahan hukum primer, penelitian ini juga menggunakan bahan-bahan hukum sekunder. Bahan-bahan hukum sekunder berupa semua publikasi tentang hukum yang bukan merupakan dokumen-dokumen resmi. ${ }^{9}$ Bahan-bahan hukum sekunder yang digunakan dalam penelitian ini, antara lain buku-buku literatur, kamus hukum, jurnaljurnal hukum, serta komentar-komentar para ahli atas putusan pengadilan. Terutama yang berkaitan dengan waralaba dan rahasia dagang.

\footnotetext{
${ }^{5}$ Peter Mahmud Marzuki, 2007, Penelitian Hukum, Kencana Prenada Media Group, Jakarta, hlm. 93.

${ }^{6}$ Ibid., hlm. 95.

${ }^{7}$ Ibid.. hlm. 141

${ }^{8}$ Ibid

${ }^{9}$ Ibid.
} 
Website : http://yustisia.unmermadiun.ac.id/index.php/yustisia

\section{Prosedur Pengumpulan Bahan Hukum}

Prosedur pengumpulan bahan hukum untuk penelitian ini dilakukan dengan cara inventarisasi dan kategorisasi. Sumber bahan hukum yang telah dikumpulkan kemudian dikategorikan. Selanjutnya, sumber bahan hukum yang telah dikumpulkan dan dikategorikan tersebut berdasarkan cara studi kepustakaan dilakukan dengan mempelajari pendapat para ahli yang tertuang dalam buku-buku literatur, kamus hukum, jurnal-jurnal hukum, dan majalah hukum. Apabila berkaitan dengan rumusan masalah yang sedang dibahas dapat dilakukan pengutipan jika diperlukan.

\section{Analisa Bahan Hukum}

Dalam penelitian ini, semua bahan hukum, baik sumber bahan hukum primer maupun sumber bahan hukum sekunder, dianalisis dengan menggunakan metode deduktif, yaitu metode yang menganalisis ketentuan-ketentuan hukum sebagai suatu hal yang umum kemudian ditarik kesimpulan yang bersifat khusus.

\section{HASIL DAN PEMBAHASAN}

\section{Perlindungan Hukum Terhadap Pemilik Rahasia Dagang Dalam Perjanjian Waralaba.}

Sebagai negara yang berkembang, Indonesia perlu mengupayakan adanya persaingan yang tangguh di kalangan dunia usaha. Hal ini sejalan dengan kondisi global di bidang perdagangan dan investasi. Daya saing semacam ini telah lama dikenal dalam sistem Hak Kekayaan Intelektual, misalnya paten. Dalam paten sbagai imbalan atas hak esklusif yang diberikan oleh negara, penemu harus mengungkapkan temuan atas invensinya itu. Namun, tidak semua penemu atau kalangan pengusaha bersedia mengungkapkan temua atau invensinya itu. Mereka ingin tetap menjaga kerahasiaan karya intelektual mereka. ${ }^{10}$ Untuk kepentingan itulah maka diberikan perlindungan Rahasia Dagang dalam Hak Kekayaan Intelektual.

Dalam pasal 1 butir (1) Undang-Undang Nomor 30 tahun 2000 tentang Rahasia Dagang disebutkan bahwa rahasia dagang adalah informasi yang tidak diketahui umum di bidang teknologi dan bisnis, mempunyai nilai ekonomis karena berguna dalam kegiatan usaha dan dijaga kerahasiaannya oleh pemilik rahasia dagang. ${ }^{11}$

Dari rumusan pasal 1 butir (1) Undang-Undang Nomor 30 Tahun 2000 Tentang Rahasia Dagang tersebut, dapat disebutkan beberapa unsur rahasia dagang yaitu :

1. Terdapat informasi,

2. Informasi tersebut tidak diketahui umum atau tertutup,

3. Informasi di bidang teknologi atau bisnis,

4. Informasi tersebut mempunyai nilai ekonomis (komersial), dan

5. Informasi tersebut oleh pemiliknya dilindungi dengan langkah-langkah bersifat protektif. ${ }^{12}$

Undang-Undang Rahasia Dagang telah mengakui sifat kerahasiaan informasi tersebut akan bersifat tetap (permanen), selama hal itu dikehendaki oleh pemilik informasi. Hal demikian itu sekaligus sebagai bentuk pengakuan oleh undang-undang terhadap keeksklusifaninformasi yang bersangkutan. Dengan demikian, patutlah dilindungi sebagai hak milik keperdataan. ${ }^{13}$

\footnotetext{
${ }^{10}$ Penjelasan Umum Undang-Undang Nomor 30 Tahun 2000 Tentang Rahasia Dagang

${ }^{11}$ Pasa 1 butir (1) Undang-Undang Nomor 30 Tahun 2000 Tentang Rahasia Dagang

${ }^{12}$ Hendra Djaja, 2009, Hukum Hak Kekayaan Intelektual (Prinsip Dasar Dan Norma Perlindungan Varietas Tanaman - Rahasia Dagang - Desain Industry - Desain Tata Letak Sirkuit Terpadu - Paten- Merek- Hak Cipta), Surya Pena Gemilang, Jakarta, hlm. 58

${ }^{13}$ Ibid, hlm 58-59
} 
Website : http://yustisia.unmermadiun.ac.id/index.php/yustisia

Lingkup Rahasia Dagang meliputi metode produksi, metode pengolahan, metode penjualan dan informasi lain di bidang teknologi dan/atau bisnis yang memiliki nilai ekonomi dan tidak diketahui masyarakat umum. ${ }^{14}$ bersifat :

Suatu rahasia dagang akan mendapatkan perlindungan apabila informasi tersebut

a. Bersifat rahasia, maksudnya bahwa informasi tersebut hanya diketahui oleh pihak tertentu atau tidak diketahui secara umum oleh masyarakat. Berdasarkan hal ini, maka pemilik rahasia dagang harus dapat membuktikan bahwa informasi itu benar-benar hanya diketahui oleh perusahaannya bukan merupakan informasi yang berifat umum.

b. Mempunyai nilai ekonomi, maksudnya bahwa sifat kerahasiaan informasi tersebut dapat digunakan untuk menjalankan kegiatan usaha yang bersifat komersial atau dapat meningkatkan keuntungan secara ekonomi.

c. Informasi dianggap dijaga kerahasiaannya, pemilik rahasia dagang harus menjaga informasi yang bersifat rahasia dari pihak-pihak lain yang dapat merugikan kepentingannya. Undang-undang rahasia dagang memberikan penjelasan pemilik rahasia dagang telah menjaga rahasia dagangnya apabila telah melakukan langkah-langkah yang layak dan patut. Namun undang-undang tersebut tidak menjelaskan lebih lanjut tentang hal tersebut. ${ }^{15}$

Rahasia dagang sebagai aset perusahaan yang sangat berharga harus dijaga sampai kapanpun tanpa batas waktu. Apabila rahasia tersebut sampai terungkap kepada pihak lain, baik terhadap perusahaan yang melakukan perdagangan yang sejenis, maupun yang tidak sejenis tetap akan membawa kerugian bagi penemu. Untuk itu perlu dijaga sifat kerahasiannya dan perlu mendapatkan perlindungan. ${ }^{16}$

Perlindungan rahasia dagang yang diberikan, pada hakikatnya bersumber pada

hubungan keperdataan antara pemilik rahasia dagang dan pemegang rahasia dagang atau penerima lebih lanjut hak rahasia dagang dalam bentuk lisensi rahasia dagang dengan pihak ketiga yang tidak berhak untuk melakukan tindakan yang secara komersial memanfaatkan rahasia dagang tersebut, termasuk yang melakukan pemberian informasi rahasia dagang secara tidak benar, dan yang memperolehnya secara berlawanan dengan hukum. Hubungan keperdataan ini banyak dilakukan oleh para pengusaha untuk mengembangkan bisnisnya. Salah satu bentuk pengembangan bisnis yang banyak diminati pengusaha adalah perjanjian waralaba. Waralaba banyak bersinggungan dengan Hak Kekayaan Intelektual termasuk rahasia Dagang yang memang rawan terjadi pelanggaran karena berkaitan dengan informasi perusahaan yang sifatnya rahasia.

Oleh karena itu dalam mengembangkan usaha bisnis dalam bentuk waralaba pemilik perusahaan harus sangat berhati-hati agar rahasia dagangnya tidak dibocorkan oleh mitra bisnisnya termasuk pegawai/karyawan yang bekerja pada perusahaannya maupun perusahaan mitra bisnisnya. Pemilik rahasia dagang harus melindungi rahasia dagangnya agar tidak dimanfaatkan oleh pihak lain.

Perlindungan hukum rahasia dagang dalam suatu bisnis waralaba dapat dilaksanakan melalui perjanjian waralaaba. Perjanjian waralaba merupakan perjanjian innominaat sebagaimana diatur dalam pasal 1319 Kitab Undang-Undang Hukum Perdata (KUHPerdata) dan tunduk pada pasal 1320 dan 1338 KUHPerdata.

Pengaturan perjanjian waralaba juga diatur dalam Peraturan Pemerintah Nomor 42 Tahun 2007 Tentang Waralaba Dan Peraturan Menteri Perdagangan Republic Indionesia

\footnotetext{
${ }^{14}$ Pasal 2 Undang-Undang Nomor 30 Tahun 2000 Tentang Rahasia Dagang

15 Muhammad Djumhana dan R. Djubaedillah, 2014, Hak Milik Intelektual, PT Citra Aditya Bakti, Bandung, hlm. 354

${ }^{16}$ Lanny Kusumawaty, 2005, Pemahaman Rahasia Dagang, Srikandi, Surabaya, hlm. 15. 
Website : http://yustisia.unmermadiun.ac.id/index.php/yustisia

Nomor 31/M_DAG/PER/8/2008 Tentang Penyelenggaraan Waralaba. Selain Itu Dalam Keputusan KPPU N0. 57/Kppu/Kep/III/2009 Tentang Pedoman Pelaksanaan Ketentuan Pasal 50 Huruf (B) Undang-Undang Nomor 5 Tahun 1999 Tentang Larangan Praktek Monopoli Dan Persaingan Usaha Tidak Sehat Terhadap Perjanjian Yang Berkaitan Dengan Waralaba Yang Memberikan Batasan-Batasan terhadap Klausul Perjanjian Waralaba.

Perlindungan terhadap rahasia dagang dalam format bisnis waralaba dapat dilakukan dengan membuat perjanjian waralaba yang memuat klausul confidential information untuk megidentifikasikan hal-hal apa saja yang termasuk ke dalam rahasia dagang yang dimiliki oleh pemilik waralaba. Selain itu perjanjian waralaba juga harus memuat klausul non disclosure agreement yang merupakan kesepakatan suatu pihak untuk tidak mengungkapkan informasi rahasia dagang kepada pihak lain. ${ }^{17}$

Kemudian setelah perjanjian waralaba berakhir maka perjanjian waralaba harus memuat non compete agreement ketentuan yang menyatakan bahwa penerima waralaba dilarang membangun, menjalankan atau meniru usaha yang sejenis, memiliki kemiripan atau yang dapat menciptakan kompetisi dengan usaha waralaba yang diberikan dan dimiliki oleh pihak pemberi waralaba, maka seluruh kerugian investasi pihak pemberi waralaba menjadi risiko pihak penerima waralaba. Hal ini dapat mencegah digunakannya rahasia dagang oleh mantan penerima waralaba untuk membuka usaha bisnis yang sama yang timbul terjadinya persaingan tidak sehat. ${ }^{18}$

Non compete agreement boleh diperjanjikan sepanjang hal itu digunakan untuk melindungi Hak Kekayaan Intelektual pemberi waralaba juga untuk menjaga identitas dan reputasi usaha waralaba. Klausul ini dalam jangka waktu yang lama tidak diperbolehkan karena dapat menghambat persaingan dan perkembangan teknologi. ${ }^{19}$

Perjanjian waralaba juga harus memiliki klausul non solicitation agreement yang merupakan larangan penghasutan terhadap pelanggan maupun karyawan pemberi waralaba. Disamping itu dalam perjanjian waralaba juga harus dimasukkan klausul-klausul yang memuat sanksi - sanksi terhadap pelanggaran klausul non disclosure, non compete dan non solicitation agreement tersebut agar klausul-klausul tersebut nantinya dapat tidak menjadi klausul-klausul belaka tetapi dapat ditegaskan berlakunya. ${ }^{20}$

\section{Akibat Hukum Jika Terjadi Pelanggaran Terhadap Rahasia Dagang Dalam Perjanjian Waralaba}

Waralaba meliputi bentuk-bentuk metode produksi dan distribusi barang atau jasa kepada konsumen dengan suatu standard dan sistem eksploitasi tertentu. Standar dan eksploitasi tersebut meliputi kesamaan dan penggunaan nama perusahaan, merek, serta sistem produksi, tata cara pengemasan, penyajian dan pengedarannya sehingga pihak penerima waralaba diwajib membayar imbalan pemakaian hak terwaralaba karena pemberi waralaba telah mengijinkan menggunakan nama dagang serta metode pelaksanaan usahanya kepada penerima waralaba yang komersial. ${ }^{21}$

Perjanjian waralaba merupakan perjanjian jenis baru yang tumbuh dan berkembang dalam praktek sehari-hari, sehingga belum diatur secara khusus dalam KUH perdata, melainkan diatur sendiri di dalam Peraturan Pemerintah Nomor 42 Tahun 2007 tentang waralaba.

\footnotetext{
17 Muhammad Faisal, 2012, Tinjauan Yuridis perjanjian rahasia dagang dalam perjanjian waralaba, skirpsi, Fakultas Hukum, Universitas Indonesia, Jakarta, hlm. 64

${ }^{18}$ Privat Law, op cit, hlm. 93

${ }^{19}$ Muhammad Faisal, op cit, hlm. 56

${ }^{20}$ ibid

${ }^{21}$ Bella Katrinasari, Hernawan Hadi, op cit, hlm. 89
} 
Website : http://yustisia.unmermadiun.ac.id/index.php/yustisia

Menurut pasal 1 ayat 1 Peraturan Pemerintah Nomor 42 Tahun 2007 tentang waralaba, menyebutkan bahwa waralaba merupakan hak khusus yang dimiliki oleh orang perseorangan atau badan usaha terhadap bisnis dengan ciri khas usaha dalam rangka memasarkan barang dan atau jasa yang telah terbukti berhasil dan dapat dimanfaatkan dan/atau digunakan oleh pihak lain berdasarkan perjanjian waralaba.

Berdasarkan penjelasan pasal 3 huruf a Peraturan Pemerintah nomor 42 tahun 2007 yang dimaksud dengan ciri khas usaha adalah suatu usaha yang memiliki keunggulan atau perbedaan yang tidak mudah ditiru, dibandingkan dengan usaha lain sejenis, dan membuat konsumen selalu di atas adalah:

a. Adanya hak khusus

b. Pelakunya perseorangan maupun badan usaha

c. Adanya obyek sistem bisnis dengan ciri khas usaha

d. Tujuannya memasarkan barang dan/atau jasa yang telah terbukti berhasil dan dapat dimanfaatkan dan/ atau digunakam oleh pihak lain.

e. Dasarnya perjanjian waralaba.

Perjanjian waralaba merupakan perjanjian tidak bernama atau perjanjian innominat, karena perjanjian waralaba merupakan perjanjian yang tidak bernama, sumber perjanjian adalah pasal 1338 KUH Perdata yang dalam pasal ini mengandung asas kebebasan berkontrak. ini berarti hukum perjanjian yang berisi apa saja yang dibuat secara sah berlaku sebagai undang-undang bagi mereka yang membuatnya selama tidak bertentangan dengan undangundang, kesusilaan dan ketertiban umum. ${ }^{22}$

Ada kalanya dalam pelaksanaan perjanjian mungkin saja akan menghadapi hal-hal yang menghambat bahkan menyebabkan tidak terpenuhinya perjanjian tersebut. Apabila dalam suatu perjanjian pihak yang mempunyai kewajiban tidak melaksanakan kewajibannya, tentu akan menimbulkan kerugian bagi kreditur. Suatu kesepakatan perjanjian tidak dilaksanakan dengan baik oleh salah satu pihak dalam suatu perjanjian waralaba, pihak yang tidak sengaja wanprestasi dapat terjadi karena memang tidak mampu untuk memenuhi prestasi tersebut atau juga karena terpaksa untuk tidak melakukan prestasi tersebut. ${ }^{23}$

Wanprestasi dalam perjanjian waralaba yang berkaitan dengan rahasia dagang dapat berupa pelanggaran hak rahasia dagang yang dengan sengaja diungkapkan oleh pihak yang telah mengetahui informasi yang seharusnya dirahasiakan. Pihak-pihak tertentu ini misalnya penerima waralaba, pegawai/karyawan perusahaan atau pemegang rahasia dagang.

Pasal 13 Undang-Undang Nomor 30 tahun 2000 tentang Rahasia Dagang menyebutkan bahwa "pelanggaran terhadap rahasia dagang juga terjadi apabila sesorang dengan sengaja mengungkapkan rahsia dagang, mengingkari kesepakatan, atau mengingkari kewajiban tertulis untuk menjaga rahasia dagang bersangkutan."

Selanjutnya pasal 14 Undang-Undang Nomor 30 tahun 2000 tentang Rahasia Dagang juga menyebutkan " sesorang dianggap melanggar rahasia dagang pihak lain apabila ia memperoleh atau menguasai rahasia dagang tersebut debngan cara yang bertentangan dengan peraturan perundang-undangan."

Ketentuan pasal 13 dan pasal 14 diatas mengatur beberapa modus pelanggaran rahasia dagang sebagai hak milik yang bersifat perseorangan. Namun demikian harus kita pula bahwa rahasia dagang sebagai salah satu obyek HKI, tentu saja, melekat prinsip sosial sebagaiman objek HKI lainnya. Apabila hak keprdataan tersebut, pemilik maupun pemegang rahsia dagang dapat melakukan penuntutan. ${ }^{24}$

\footnotetext{
${ }^{22}$ Munir Fuady, 2015, Konsep Hukum Perdata, Rajawali Press,Jakarta, hlm.181

${ }^{23}$ Ahmadi Miru, 2007, Hukum Kontrak dan Perancangan Kontrak, Raja Grafindo, Jakarta, hlm. 74

${ }^{24}$ Hendra Djaja, op cit, hlm. 66
} 
Website : http://yustisia.unmermadiun.ac.id/index.php/yustisia

Beberapa perbuatan atau pelanggaran yang dikatagorikan sebagai pelanggaran hak rahasia dagang antara lain :

a. dengan sengaja mengungkapkan rahasia dagang,

b. mengingkari kesepakatan,

c. mengingkari kewajiban tertulis untuk menjaga rahasia dagang, dan

d. memeperoleh atau menguasai rahasia dagang yang bertentangan dengan peraturan perundang-undangan. ${ }^{25}$

Hak rahasia dagang merupakan hak keperdataan sehingga pemilik rahasia dagang bebas untuk melakukan kesepakatan dengan pihak lain untuk mengeksploitasi hak yang dimiliki dalam suatu kegiatan usaha yang menguntungkan secara ekonomis. Hubungan hukum tersebut dilindungi oleh negara sehingga jika terjadi pelanggaran oleh pihak ketiga secara melawan hukum, perbuatan pihak ketiga tersebut merupakan dialektual sehingga pemilik rahasia dagang dapat melakukan tuntutan atau gugatan. ${ }^{26}$

Adapun substansi gugatan yabng dapat dilakukan adalah ganti rugi atau penghentian sementara semua perbuatan seperti yang telah disebutkan. Selain penyelesaian gugatan melalui pengadilan negeri, para pihakdapat pula menyelesaiakan perselisihan diantara mereka melalui arbitrase atau alternative penyelesaian sengketa baik negosiasi, konsiliasi, maupun cara lain yang dipilih oleh para pihak, sesuai dengan peraturan perundang-undangan yang berlaku. ${ }^{27}$

Pasal 1243 KUH Perdata menyatakan bahwa:

"Penggantian biaya, kerugian dan bunga karena tak dipenuhinya suatu perikatan mulai diwajibkan, bila debitur, walaupun telah dinyatakan Ialai, tetap Ialai untuk memenuhi perikatan itu, atau jika sesuatu yang harus diberikan atau dilakukannya hanya dapat diberikan atau dilakukannya dalam waktu yang melampaui waktu yang telah ditentukan”.

Ketentuan kedua pasal tersebut di atas menentukan bahwa dalam hal debitur lalai untuk memenuhi kewajiban prestasinya, kreditur berhak untuk menuntut penggantian kerugian, biaya dan bunga.

Sanksi bagi seorang debitur yang lalai dalam berprestasi, yaitu :

a. Membayar kerugian yang diderita oleh kreditur atau ganti rugi

b. Pembatalan perjanjian atau juga dinamakan pemecahan perjanjian

c. Peralihan resiko

d. Membayar biaya perkara kalau sampai diperkarakan di depan pengadilan.

Ada dua sebab timbulnya ganti rugi, yaitu ganti rugi karena wanprestasi dan ganti rugi karena perbuatan melawan hukum. Ganti rugi karena wanprestasi diatur dalam Buku III KUH Perdata dimulai dari Pasal 1243 KUH Perdata sampai dengan Pasal 1252 KUH Perdata, sedangkan ganti rugi karena perbuatan melawan hukum diatur dalam Pasal 1365 KUH Perdata. Ganti rugi karena perbuatan melawan hukum adalah suatu bentuk ganti rugi yang dibebankan kepada orang menimbulkan kesalahan kepada pihak yang dirugikannya. Ganti rugi itu timbul karena adanya kesalahan. Ganti rugi karena wanprestasi adalah suatu bentuk ganti rugi yang dibebankan karena tidak memenuhi isi perjanjian yang telah dibuat antara pemberi waralaba dan penerima.

Di samping aspek perdata, Undang-Undang Nomor 30 Tahun 2000 tentang Rahasia Dagang juga mengatur aspek pidana yang berhubungan dengan pelanggaran hak rahasia dagang. Aspek pidana ini memang diperlukan untuk melindungi pemilik maupun pemegang hak rahasia dagang yang beritikad baik. ${ }^{28}$

\footnotetext{
${ }^{25} \mathrm{ibid}$

${ }^{26}$ ibid

${ }^{27}$ Hendra Djaya, op.cit, hlm 68

${ }^{28}$ ibid
} 
Website : http://yustisia.unmermadiun.ac.id/index.php/yustisia

Tindak pidana pelanggaran hak rahasia dagang diatur dalam pasal 17 ayat (1) UndangUndang Nomor 30 tahun 2000 tentang Rahasia Dagang, antara lain menyebutkan :

"barangsiapa dengan sengaja dan tanpa hak menggunakan rahasia dagang pihak lain, atau melakukan perbuatan dengan sengaja mengungkap rahasia dagang pihak lain, mengingkari kesepakatan atau mengingkari kewajiban tertulis; atau menguasai rahasia dagang dengan cara bertentangan dengan perundang-undangan dipidana dengan pidana penjara paling lama dua tahun dan/atau denda paling banyak $\mathrm{Rp} 300.000 .000,00$ (tiga ratus juta rupiah).

Selanjutnya pasal 17 ayat (2) Undang-Undang Nomor 30 tahun 2000 tentang Rahasia Dagang bahwa tindak pidana pelanggaran rahasia dagang merupakan delik aduan. Hal ini berarti proses perkara pidana baru dilakukan apabila ada pengaduan dari pemilik rahasia dagang atau oleh penerima lisensi karena perbuatan pihak ketiga yang memperoleh informasi rahasia dagang dengan cara melawan hukum. ${ }^{29}$

\section{E. KESIMPULAN}

Perlindungan hukum terhadap pemilik rahasia dagang dalam perjanjian waralaba dapat dilakukan dengan memasukkan klausul confidential agreement, non disclosure agreement dalam perjanjian waralaba. Klausul confidential agreement menentukan hal-hal apa saja yang termasuk ke dalam informasi yang dirahasiakan.

Non disclosure agreement merupakan kesepakatan suatu puhak untuk tidak mengungkapkan informasi rahasia milik pihak lainnya. Klausul ini digunakan untuk melindungi informasi-informasi rahasia yang tidak boleh diketahui oleh umum. Sedangkan perlindungan setelah berakhirnya perjanjian waralaba dapat difasilitasi dengan memasukkan klausul non compete agreement yang merupakan suatu klausul dimana suatu pihak setuju untuk tidak menyaingi usaha pihak lain dalam suatu usaha bisnis yang spesifik dalam jangka waktu tertentu dan geografis tertentu. Untuk mencegah persaingan usaha yang tidak sehat dapat dilakukan dengan klausul non solicitation agreement yang merupakan larangan penghasutan terhadap pelanggan maupun karyawan pemberi waralaba. Akibat hukum jika terjadi pelanggaran terhadap rahasia dagang dalam perjanjian waralaba adalah dapat dituntut secara perdata dengan membayar ganti rugi melalui gugatan ke pengadilan atau dapat diselesaikan melalui jalur arbitrase atau alternatif penyelesaian sengketa. Selain itu dapat juga dituntut secara pidana sesuai pasal 17 ayat (1) Undang-Undang Nomor 30 tahun 2000 tentang Rahasia Dagang dengan ancaman hukuman pidana penjara paling lama dua tahun dan denda paling banyak tiga ratus juta rupiah.

\section{F. DAFTAR PUSTAKA}

\section{Literatur :}

Ahmadi Miru, 2007, Hukum Kontrak dan Perancangan Kontrak, Raja Grafindo, Jakarta

Hendra Djaja, 2009, Hukum Hak Kekayaan Intelektual (Prinsip Dasar Dan Norma Perlindungan Varietas Tanaman - Rahasia Dagang - Desain Industry - Desain Tata Letak Sirkuit Terpadu - Paten-Merek- Hak Cipta), Surya Pena Gemilang, Jakarta

Lanny Kusumawaty, 2005, Pemahaman Rahasia Dagang, Srikandi, Surabaya

Muhammad Djumhana dan R. Djubaedillah, 2014, Hak Milik Intelektual, PT Citra Aditya Bakti, Bandung

\footnotetext{
${ }^{29}$ Ibid, hal. 69
} 
Website : http://yustisia.unmermadiun.ac.id/index.php/yustisia

Munir Fuady, 2015, Konsep Hukum Perdata, Rajawali Press,Jakarta,

Peter Mahmud Marzuki, 2007, Penelitian Hukum, Kencana Prenada Media Group, Jakarta

\section{Jurnal/skripsi :}

Anik Tri Haryani, 2017, Perlindungan Hukum HAKI Dalam Perjanjian Waralaba, Justitia Merdeka, Volume 3, Nomor 1, Maret 2017, LPPM, Universitas Merdeka Madiun

Bella Katrinasari, Hernawan Hadi, 2017, Tinjauan Hukum Terhadap Wanprestasi Royalty Rahasia Dagang Dalam Perjanjian Waralaba, Privat Law, Vol. V, Januari 2017, Universitas Sebelas Maret, Surakarta

Muhammad Faisal, 2012, Tinjauan Yuridis Perjanjian Rahasia Dagang Dalam Perjanjian Waralaba, skirpsi, Fakultas Hukum, Universitas Indonesia, Jakarta

Peraturan perundang-undangan

Undang-Undang Nomor 30 Tahun 2000 Tentang Rahasia Dagang 